\title{
METAMORFOSA PARADIGMA PERPUSTAKAAN; Dari not for profit sector menuju income generating unit dengan pemasaran perpustakaan
}

\section{Oleh: Dian Arya}

\begin{abstract}
Abstrak
Perpustakaan sudah dikenal sebagai sebuah sebuah organisasi non profit yang menyediakan jasa penyediaan informasi tanpa mengharapkan imbalan. Paradigma tersebut seyogianya berubah, agar pendanaan dari lembaga penaung tidak lagi menjadi satu-satunya harapan untuk berkembang. Perpustakaan harus bermetamorfosa agar bisa membiayai dirinya sendiri, dan terus berkembang sesuai dengan tuntutan zaman. Hal ini tentunya dimungkinkan bila perpustakaan mau mengaplikasikan prinsip-prinsip marketing dalam proses dan sistem layanan.
\end{abstract}

Kata Kunci: metamorfosa perpustakaan, paradigma perpustakaan, not for profit sector, income generating unit, pemasaran perpustakaan

A. Pendahuluan

Condisi perpustakaan di $90 \%$ diantaranya belum memiliki infrastruktur lengkap, termasuk sumber daya manusianya (Suwardi, 2006). Hal ini berpengaruh pada kualitas layanan perpustakaan dan akhirnya pada keselamatan perpustakaan itu sendiri. Karena buruknya pelayanan lambat laun perpustakaan akan ditinggalkan oleh penggunanya. Padahal perpustakaan ada karena pengguna ada. Bila suatu saat badan induk tidak lagi merasakan esensi penting dari sebuah perpustakaan, maka Adios! Perpustakaan akan menjadi suatu organisma yang hidup segan mati tak mau.
Sementara, dunia di luar terus berkembang. Laju informasi begitu deras mengalir, menjajari format lama layanan informasi yang disediakan oleh perpustakaan. Buku yang berjajar di rak, dengan susunan yang (pada umumnya) tidak teratur, akses temu kembali informasi yang tidak user friendly, hasil temuan telusuran yang tidak sesuai keadaan, fasilitas layanan yang tidak mengutamakan kepentingan pengguna, pelayanan yang tidak sesuai standar, kesemua itu merupakan hal-hal yang bisa menyebabkan perpustakaan lambat laun kehilangan penggunanya. Masalah-masalah itulah yang menggelantungi pikiran para manajer perpustakaan selama ini. 
Sebetulnya hal ini disebabkan oleh paradigma-paradigma lama yang saat ini bercokol di benak dan pikiran para pustakawan. Untuk bisa selamat, pustakawan, sebagai pengelola perpustakaan harus mau mengubah diri dengan mengubah paradigma lama dengan paradigma baru, karena seperti yang dikatakan Weingand dalam Hawcroft (s.a) "...libraries must develop creative problem-solving strategies if they are not only to survive but to thrive.".

\section{B. Metamorfosa Paradigma Perpustakaan}

Tintin Sastraatmadja dalam pidato ilmiahnya menuliskan bahwa "sebagai sub sistem dari lembaga induknya, perpustakaan...mempunyai tugas utama dan fungsi. ...tugas utamanya untuk memberikan pelayanan terbaik dalam penyediaan dan pelayanan informasi dalam menunjang tugas pokok dan fungsi lembaga induknya. Tugas tersebut terdiri dari empat fungsi. Yang pertama yaitu; mengumpulkan, menyusun, melestarikan, dan menyediakan bahan perpustakaan dan sumber informasi lain yang relevan untuk menunjang tugas lembaga induknya. Fungsi yang kedua yaitu; menganalisa, mengolah, mendaftar dan menginformasikan pustaka yang ada kepada semua pengguna. Fungsi ketiga adalah mengikuti perkembangan sistem kepustakaan sesuai perkembangan IPTEK. Dan yang keempat adalah ikut mendorong meningkatnya kebiasaan dan kemampuan membaca serta menulis di kalangan para penggunanya."

Beliau juga mengatakan,
dalam kaitannya globalisasi, perlu ada peningkatan daya saing pada pelayanan jasa informasi di perpustakaan secara umum, yang dimaksudkan sebagai upaya menerapkan paradigma baru tentang strategi kompetitif agar mampu mengadaptasi gejolak perubahan eksternal serta memanfaatkan peluang. Konsep ini mengacu pada perubahan sistem layanan jasa perpustakaan dan informasi yang menjadi jauh lebih luas daripada sekedar layanan peminjaman buku, layanan referensi, layanan penelusuran dan lain-lain. Selain itu, perpustakaan juga harus berani menampilkan 'wajah baru' dalam arti menampilkan terobosan baru dan paradigma baru yaitu dapat mengubah persepsi masyarakat dari perpustakaan identik dengan buku menjadi perpustakaan indentik dengan informasi. Dari pustakawan sebagai pelayan informasi menjadi pustakawan sebagai transponder dan provider informasi.

Semua perpustakaan pasti memiliki tujuan yang sama, yaitu memenuhi kebutuhan 
penggunanya, "Giving the right book to the right person at the right time". Tetapi perpustakaan pada umumnya menghadapi sebuah dilema, yaitu keinginan untuk mengembangkan sumber daya yang dimiliki untuk memenuhi kebutuhan pengguna, yang harus berhadapan dengan keterbatasan dana yang disediakan oleh badan induknya.

Akan tetapi paradigma yang kebanyakan tertanam dalam hati setiap pengelola perpustakaan adalah bahwa perpustakaan bukanlah lembaga penghasil uang. Sulistyo Basuki dalam Pengantar Ilmu Perpustakaan menuliskan bahwa "Perpustakaan merupakan unit yang mengeluarkan uang, bukannya unit yang mampu menghasilkan uang". Barbara E. Chernik juga dalam bukunya Introduction to Library Services for Library Teechnicians (1982) menyatakan "The finances of the library may come from the governing authority in a variety of ways". Dari pernyataan-pernyataan ini, bisa diartikan bahwa perpustakaan adalah sebuah not for profit sector, sebuah sektor non profit yang tujuan dari kegiatannya bukanlah untuk menghasilkan uang, dan walaupun ada kegiatannya yang menghasilkan uang, tetap dianggap tidak cukup untuk bisa membiayai dirinya sendiri. Semua pendanaan perpustakaan berasal dari badan induk, baik secara langsung maupun tidak langsung.

Ketergantungan terhadap badan induk ini seringkali menjadikan perpustakaan sulit untuk berkembang. Hal ini diperkuat oleh sebuah tradisi yang sudah mengurat akar di hati bangsa ini. Secara umum Putu Laxman Pendit dalam makalahnya yang berjudul Otonomi Perpustakaan (2001) menyatakan bahwa “Kepustakawanan Indonesia tumbuh dalam lingkungan informasi yang berakar pada tradisi yang membenarkan pusat kekuasaan sebagai sekaligus pusat dan sumber informasi.". Intervensi pemerintah dan lembaga elit sangat berpengaruh terhadap arah pengembangan kepustakawanan Indonesia.

Keadaan serba ketergantungan pada badan induk menyebabkan keadaan yang konstan dan pasti, yang membuat pustakawan kurang termotivasi untuk berprestasi. Bekerja atau tidak, mengembangkan diri atau tidak, pustakawan dan perpustakaan akan tetap menerima suntikan dana. Berawal dari paradigma tersebut, pustakawan yang bertugas mengelola perpustakaan untuk memenuhi tujuan perpustakaan, sekaligus tujuan badan induk, menjadi tidak terbiasa untuk melakukan yang terbaik untuk 
organisasinya. Semua dilakukan seadanya, bukan semampunya. Pelayanan bagi pengguna menjadi tidak maksimal terutama ketika mentalitas dan wawasan keilmuan sumber daya perpustakaan (pustakawan) masih memprihatinkan (Hartanto, 2006). Ketidaktahuan menyebabkan ketidaksepahaman antara pustakawan, pengguna dan badan induk. Hamon dalam Hawcroft (s.a) menyebutkan, mungkin kelemahan terbesar dalam usaha untuk memasarkan layanan perpustakaan secara tradisional yaitu kegagalan dalam membangun sebuah citra mengenai kebutuhan atau bahkan persepsi mengenai kebutuhan itu sendiri, terhadap produk perpustakaan dalam pemikiran para pengambil keputusan.

Perpustakaan harus mampu mewujudkan dan bisa menunjukkan bahwa dirinya telah menjadi sebuah organisasi penyedia layanan informasi yang efektif dan efisien, yang mampu memenuhi keinginan dan kebutuhan pengguna, yang sesuai dengan apa yang telah digariskan oleh badan induk. Koleksi dan jasa layanan informasi yang cepat, tepat dan bermutu (dari sudut pandang pengguna) akan meningkatkan pemanfaatan perpustakaan dan menjadi tolak ukur keberhasilan perpustakaan secara keseluruhan. Bila tidak demikian, perpustakaan akan jauh tertinggal dari penyedia layanan berbasis teknologi informasi yang semakin hari semakin berkembang.

Paradigma ini harus dirubah. Perpustakaan harus bisa berdiri diatas kakinya sendiri. Ketergantungan dana terhadap badan induk harus sedikit demi sedikit dikurangi dengan melakukan pemasaran perpustakaan. Seperti ulat menjadi kupu-kupu, perpustakaan harus mulai bermetamorfosa menjadi sebuah organisasi yang lebih baik. Perpustakaan harus bisa mengembangkan sayapnya, sesuai dengan perkembangan teknologi informasi, dan bertahan dalam arus globalisasi dengan menjadi sebuah income generating unit.

\section{Selintas Mengenai Pemasaran 1. Pemasaran, Apa dan Mengapa}

Terdapat banyak sekali definisi pemasaran yang terus menerus berkembang sesuai dengan perkembangan pemasaran itu sendiri. Dalam bukunya, Manajemen Pemasaran Edisi ke 11 Jilid pertama (2005), Kotler membedakan definisi pemasaran menjadi dua bagian, yaitu definisi pemasaran secara sosial dan secara manajerial. Definisi sosial menunjukkan peran yang dimainkan oleh pemasaran di masyarakat, yaitu sebuah proses sosial yang dengan proses itu 
individu dan kelompok mendapatkan apa yang mereka butuhkan dan inginkan dengan menciptakan, menawarkan dan secara bebas mempertukarkan produk dan jasa yang bernilai dengan pihak lain. Sedangkan definisi manajerial lebih sebagai seni dan ilmu untuk memilih pasar sasaran serta mendapatkan, mempertahankan, dan menambah jumlah pelanggan melalui penciptaan, penyampaian dan pengkomunikasian nilai pelangan yang unggul. Secara singkat Kotler dan Levy dalam Broadening the Concept of Marketing (1969) mengatakan bahwa "Marketing is costumer satisfaction engineering".

Coote dalam Hawcroft (s.a) mengatakan bahwa pemasaran adalah sebuah proses manajemen yang bertanggungjawab kepada pengidentifikasian, pengantisipasian, dan pemuasan pelanggan yang menghasilkan profit (the management process responsible for identifying, anticipating, and satisfying costumer requirements profitably). Pada intinya, definisi ini memberikan empat elemen pemasaran, yaitu:

1. Pemasaran adalah sebuah proses manajemen

2. Pemasaran perencanaan anticipation)

3. Pemasaran membutuhkan analisis kebutuhan pelanggan dan bagaimana memuaskan kebutuhan tersebut.

4. Pemasaran bukan hanya sekedar memberikan pelanggan apa yang mereka inginkan, tapi juga menguntungkan bagi organisasi penyedia layanan.

Perlu digarisbawahi bahwa keuntungan yang dimaksud pada definisi diatas tidak hanya terbatas dan selalu berupa masuknya uang. Yang penting disini adalah adanya mutual benefit atau keuntungan bersama. Dan inilah yang menyebabkan mengapa pemasaran lebih dipilih daripada sekedar menjual.

\section{Konsep Pemasaran}

Konsep pemasaran muncul pada pertengahan tahun 1950-an dan menantang berbagai konsep sebelumnya. Sebagai ganti filosofi "buat dan jual" yang berpusat pada produk, kita bergeser ke filosofi "pahami dan tanggapi". Sebagai ganti "berburu", pemasaran adalah "berkebun/bertani". Pekerjaan pemasaran bukan untuk menemukan pelanggan yang tepat bagi sebuah produk, melainkan menemukan produk yang tepat untuk pelanggan.

Theodore Levitt dalam Kotler (2005) menggambarkan perbedaan yang kontras antara konsep penjualan dan pemasaran, yaitu: 
1. Penjualan berfokus pada kebutuhan penjual, pemasaran berfokus pada kebutuhan pelanggan

2. Penjualan memberi perhatian pada kebutuhan penjual untuk mengubah produknya menjadi uang tunai, pemasaran memikirkan cara memuaskan kebutuhan pelanggan melalui sarana, produk dan segala sesuatu yang berkaitan dengan permasalahan menciptakan, menyerahkan dan akhirnya mengkonsumsinya.

Konsep pemasaran berdiri diatas empat pilar: pasar sasaran, kebutuhan pelanggan, pemasaran terpadu atau terintegrasi, dan kemampuan menghasilkan laba. Konsep itu dimulai dari pasar yang didefinisikan dengan baik, berfokus pada kebutuhan pelanggan, mengkoordinasikan semua aktivitas yang akan mempengaruhi pelanggan, dan menghasilkan laba dengan memuaskan pelanggan. Berikut ilustrasi yang menjelaskan keempat pilar konsep pemasaran tersebut:

\section{Pasar Sasaran}

Perusahaan-perusahaan akan berhasil secara gemilang bila mereka secara cermat memilih satu atau sejumlah pasar sasarannya dan mempersiapkan program pemasaran yang dirancang khusus untuk masingmasing pasar tesebut.

\section{Kebutuhan Pelanggan}

Perusahaan dapat mendefinisikan pasar sasaran tetapi terkadang gagal memahami kebutuhan pelanggan secara akurat. Pada intinya, pelanggan sasaran terdiri atas dua kelompok, yaitu pelanggan baru dan pelanggan lama yang membeli ulang. Adalah lebih penting untuk mempertahankan pelanggan lama dari pada menarik pelanggan baru, karena biaya yang dikeluarkan untuk menarik pelanggan baru jauh lebih mahal daripada mempertahankan pelanggan lama.

\section{Pemasaran Terpadu}

Bila semua departemen di suatu perusahaan bekerjasama untuk melayani kepentingan pelanggan, hasilnya adalah pemasaran terpadu. Pemasaran terpadu bisa terjadi pada dua level. Pertama, berbagai fungsi pemasaran harus bekerja bersama berdasarkan sudut pandang pelanggan. Kedua, pemasaran harus menjadi bagian dari departemendepartemen lain, yang juga harus memikirkan pelanggan. Pemasaran bukan sekedar departemen, melainkan orientasi perusahaan. 


\section{Kemampuan Menghasilkan}

Laba

Tujuan terakhir konsep pemasaran adalah membantu organisasi mencapai tujuannya. Dalam kasus perusahaan swasta, tujuan utama adalah laba; dalam kasus organisasi publik dan nirlaba, tujuan utama adalah bisa bertahan hidup dan mampu menarik cukup dana untuk melakukan pekerjaan yang bermanfaat.

Konsep

pemasaran

menegaskan bahwa kunci untuk mencapai sasaran organisasi adalah perusahaan harus menjadi lebih efektif dibandingkan para pesaing, dalam menciptakan, menyerahkan, dan mengkomunikasikan nilai pelanggan kepada pasar sasaran yang terpilih.

\section{Pemasaran Perpustakaan}

Perpustakaan bukanlah gudang buku. Perpustakaan adalah pusat sumber informasi yang berisi ribuan data yang siap untuk diolah dan dikonsumsi (digunakan) oleh pengguna. Elisa Ekaningsih dalam artikelnya yang berjudul Pemasaran Jasa Perpustakaan dan Informasi pada Perpustakaan Perguruan Tinggi menuliskan bahwa pemasaran adalah suatu usaha menawarkan dan mendekatkan produk kepada konsumen yang terjadi berdasarkan asas pertukaran.
Pemasaran jasa perpustakaan dapat diartikan sebagai upaya mendekatkan dan mempromosikan jasa yang diselenggarakan perpustakaan demi kepentingan pengguna serta untuk meningkatkan keefektifan informasi yang dimiliki oleh perpustakaan. Keberhasilan pemasaran jasa perpustakaan ditentukan oleh pengelola perpustakaan dalam memberikan jasa dan oleh pengguna yang mengakui bahwa jasa perpustakaan dapat memenuhi dan memuaskan kebutuhan mereka.

\section{Perpustakaan sebagai Penyedia Jasa}

Sebelum memulai pemasaran jasa perpustakaan, perlu diketahui apa yang dimaksud dengan jasa. Definisi jasa menurut Kotler (Suwardi, 2006) adalah setiap tindakan atau kegiatan yang dapat ditawarkan oleh satu pihak kepada pihak lain, yang pada dasarnya tidak berwujud dan tidak mengakibatkan kepemilikan apapun. Produksi jasa bisa dengan suatu produk fisik dan bisa pula tidak.

Menurut Fandy Tjiptono (2004) ada empat karakteristik pokok pada jasa yang membedakannya dengan barang. Keempat karakteristik tersebut meliputi:

1. Intangibility. 
Jasa bersifat intangible yang artinya tidak dapat dilihat, dirasa, diraba, dicium atau didengar sebelum dibeli.

2. Inseparability

Inseperability artinya tidak bisa dipisahkan. Berbeda dengan barang yang biasanya diproduksi dulu, baru dijual lalu dikonsumsi, produk jasa biasanya dijual terlebih dahulu baru kemudian diproduksi sekaligus langsung dikonsumsi secara bersamaan.

3. Variability

Jasa bersifat sangat variabel karena merupakan nonstandardized output, artinya produk jasa memiliki banyak variasi bentuk, kualitas dan jenis, tergantung pada siapa, kapan dan dimana jasa tersebut dihasilkan

\section{Perishability}

Jasa merupakan komoditas yang tidak tahan lama dan tidak dapat disimpan. Dengan demikian, bila suatu jasa tidak digunakan, maka jasa tersebut akan berlalu begitu saja.

Suwardi (2006) membuat sebuah analogi yang menyebutkan bahwa jasa perpustakaan adalah setiap tindakan atau kegiatan yang dapat ditawarkan oleh institusi perpustakaan kepada pengguna, baik berupa transaksi yang disertai pemindahan sementara material fisik ataupun tidak. Melihat definisi dan karakteristik jasa yang sudah disebut diatas, maka jelaslah bahwa perpustakaan merupakan sebuah organisasi penyedia jasa.

\section{Pengaplikasian Konsep Pemasaran di Perpustakaan}
a. Menjual atau memasarkan perpustakaan?

Pada dasarnya perpustakaan selalu menganut "user orientation" dalam setiap usahanya untuk menyediakan produk-produk berkualitas dalam cakupan kegiatannya. Hal ini tercermin dalam usaha perpustakaan untuk senantiasa mengembangkan koleksi, teknologi temu kembali informasi, penyediaan berbagai media yang sesuai dengan perkembangannya, dan berbagai pelayanan lain yang disesuaikan dengan kebutuhan pengguna.

Tetapi bagaimanapun, seluruh kegiatan yang dilakukan tersebut tidak pernah betul-betul fokus untuk melakukan promosi (menjual) apa yang sebenarnya ditawarkan oleh perpustakaan. Pengembangan layanan dan produk-produk yang ditawarkan terutama karena misi perpustakaan itu sendiri dan penilaian dari para "profesional" yang menentukan apa-apa yang sekiranya menjadi keinginan dan kebutuhan pengguna. 
Seperti yang sudah dibahas pada konsep pemasaran, disinilah letak perbedaan dasar antara layanan yang berfokus pada produk dan layanan yang berfokus pada pelanggan (pengguna), yang juga membedakan memasarkan dengan menjual yang hanya memiliki orientasi komersial semata. Pemasaran lebih 'memanusiakan' pengguna karena selain menghasilkan keuntungan bagi perpustakaan, perpustakaan juga betul-betul memikirkan apa yang diinginkan dan dibutuhkan oleh pengguna.

Pengguna membutuhkan perpustakaan, perpustakaan pun membutuhkan pengguna untuk bisa tetap hidup. Perpustakaan ada untuk pengguna, dan senantiasa bertujuan untuk memenuhi keinginan dan kebutuhan pengguna. Hal itu membuat pemasaran bisa lebih diterima di hati pustakawan yang ingin memajukan perpustakaan tetapi takut 'menodai misi sosial' perpustakaan dengan komersialisasi produk dan layanannya.

\section{b. Bauran pemasaran di perpustakaan}

Menurut Kotler dan Susanto, bauran pemasaran adalah kiat yang digunakan perusahaan untuk mencapai sasaran pemasarannya dalam pasar sasaran (market segementation).

McCarthy mempopulerkan pembagian kiat ini dalam empat faktor yang sering disebut $4 \mathrm{P}$, yaitu produk (product), harga (price), tempat (place) dan promosi (promotion).

Berikut adalah penjelasan untuk setiap faktor dalam bauran pemasaran ini dan kaitannya dengan pemasaran perpustakaan;

a. Produk, yang dalam konteks perpustakaan berupa layanan jasa perpustakaan. Tidak hanya sekedar layanan peminjaman dan pengembalian koleksi, jasa referensi dan fotokopi, perpustakaan juga harus mengembangkan produknya secara lebih inovatif. Sebagai sebuah penyedia jasa layanan, perpustakaan harus bisa menentukan pasar sasarannya sebelum menentukan produk yang akan dipasarkan. Bila mengingat fungsi perpustakaan, yaitu riset, pendidikan, informasi dan hiburan, maka segmentasi pasar itulah yang akan 'dijual'. Perpustakaan bukan hanya sekedar bergerak di 'industri perpustakaan', melainkan lebih kepada 'industri riset','industri pendidikan', 'industri informasi', 'industri hiburan', atau kombinasi antara keempatnya. Misalnya, dalam kaitannya dengan fungsi hiburan, peprustakaan selain menyediakan koleksi referens, 
juga harus menyediakan koleksi fiksi yang disesuaikan dengan tempat baca yang nyaman dan menyenangkan, jauh dari kesan seram. Kalau perlu disediakan tempat dengan karpet dan bantal agar pengguna bisa betul-betul merasa nyaman membaca dan menikmati buku-buku tersebut, yang tentunya dengan biaya tertentu.

b. Harga, dimana seperti yang sudah dibahas sebelumnya diawal tulisan ini bahwa perpustakaan tidak bisa lagi berorientasi non profit. Pustakawan harus mengerti konsep harga, dan mampu mengaplikasikannya dalam berbagai komponen layanannya. Dalam menentukan harga, bahwa bukan hanya biaya produksi yang menentukan harga sebuah layanan, melainkan perlu diperhatikan juga usaha dan waiting cost pengguna. Yang pasti, dalam menentukan harga layanan yang diberikan oleh perpustakaan, jangan lupa untuk tetap memikirkan kenyamanan pengguna dalam menerima harga tersebut.

c. Tempat, yang dalam konteks perpustakaan adalah lokasi dimana pengguna bisa mengakses layanan kita. Tempat menjadi sesuatu yang harus dipertimbangkan kembali dengan adanya teknologi internet, atau terdapatnya layanan yang 'mobile', atau bahkan ketika perpustakaan tetap buka di hari libur. Atau keberagaman bahasa yang terdapat dalam koleksi yang dimiliki, standar kemampuan pengguna dalam menggunakan layanan perpustakaan, dan bagaimana mereka bisa mengerti rambu-rambu yang dikeluarkan oleh perpustakaan. Intinya adalah bahwa 'tempat' dalam konteks perpustakaan berarti 'akses'.

d. Promosi, yang pada banyak perpustakaan justru dianggap hal yang paling penting. Padahal Kinnel dalam Hawcroft (s.a.) menyatakan bahwa promosi justru merupakan hal yang paling tidak penting dalam konsep bauran pemasaran. Evans dalam Hawcroft (s.a) menyatakan bahwa "promosi adalah sebuah cara untuk menunjukkan nilai profesionalisme pustakawan dan bagaimana nilai layanan yang menjadi output dari profesionalitas pustakawannya". Promosi selalu merupakan sebentuk komunikasi, tetapi tidak semua komunikasi merupakan promosi. Akan tetapi, berhubungan dengan pengguna, selalu ada saat dimana sebaiknya promosi tidak dilakukan sama sekali. 
Perlu dicatat bahwa 4P menunjukkan pandangan penjual tentang kiat pemasaran yang tersedia untuk mempengaruhi. Dari sudut pandang pembeli, setiap kiat pemasaran dirancang untuk memberikan manfaat bagi pelanggan. Robert Lauterborn dalam Kotler dan Susanto berpendapat bahwa 4P berhubungan dengan 4C pelanggan, yaitu costumers needs and wants, cost to the costumer, convinience dan communication. Jadi, perpustakaan akan berhasil memasarkan produk layanannya bila dapat memenuhi kebutuhan pelanggan secara ekonomis, mudah dan dengan komunikasi yang efektif.

\section{E. Penutup}

Tidak ada keraguan lagi, bahwa dunia terus berputar dan berubah. Teknologi informasi berkembang dan terus berevolusi untuk menghasilkan peralatan yang lebih mudah digunakan, lebih cepat, dan lebih murah. Persaingan industri menuntut pelayanan informasi yang cepat, tepat dan akurat. Dan di dunia seperti itulah perpustakaan harus berkompetisi. Tidak hanya sekedar selamat, tapi juga harus terus tumbuh dan berkembang.

Berbagai paradigma lama harus mulai ditinggalkan, dan mau tidak mau digantikan dengan berbagai paradigma baru. Pemasaran perpustakaan adalah sesuatu yang, kalau tidak wajib, merupakan tuntutan yang harus dilakukan. Hal ini dikarenakan pemasaran bisa memberikan sebuah strategi yang bisa menjamin relevansi dan eksistensi layanan perpustakaan di masa depan.

Walaupun demikian, ada beberapa hal yang harus dicermati berkaitan dengan aplikasi pemasaran di sektor non profit. Beberapa dari organisasi non profit melupakan identitas diri mereka sebagai organisasi yang lebih bertujuan sosial dari pada mencari keuntungan semata. Pencarian keuntungan bagi perusahaan menjadi tujuan utama dan melupakan misi sosial yang diembannya, serta melupakan bahwa tujuan marketing pada awalnya adalah untuk membiayai kegiatan-kegiatan yang lebih berguna, yang tidak cukup bila hanya mengandalkan dana dari badan induknya.

Perpustakaan, walau bagaimanapun adalah sebuah organisasi non profit, yang menjadi bagian dari sebuah badan induk. Jadi, implemetasi konsep pemasaran di perpustakaan harus berpegang teguh pada tujuan awalnya, menghilangkan ketergantungan suntikan dana dari badan induk, dan mengembangkan 
motivasi pustakawan untuk mau terus mengembangkan diri, karena remunerasi ditentukan oleh kompetensi, kinerja dan prestasi.

\section{G.Sumber Rujukan}

Basuki, Soelistyo.1980.Pengantar Ilmu Perpustakaan.Jakarta: Gramedia Pustaka Utama.

Chernik, Barbara E. 1982.

Introduction To Library

Services For Library

Technicians. Boston: Library

Unlimited.

Ekaningsih, Elisa. 2006. Pemasaran Jasa perpustakaan dan Informasi pada Perpustakaan perguruan Tinggi. repository.usu.ac.id/handle/12 3456789/1745

Ernawati, Endang. [n.a.]. Kompetensi, Komitmen dan Intrapreneurship Pustakawan dalam Mengelola Perpustakaan di Indonesia. journal.ipb.ac.id/index.php/jpi /article /view/2242/1263

Kotler,Philip. 2005. Manajemen Pemasaran jilid 1 ed.11. Jakarta: Salemba Empat

Kotler,Philip. 2005. Manajemen Pemasaran jilid 1 ed.11. Jakarta: Salemba Empat

Sastraatmadja, Tintin. 1996. Konsep

Peningkatan Daya Saing Pada Pelayanan Jasa Informasi di Perpustakaan.

pustakawan.pnri.go.id.

Pendit, Putu Laxman. 2001. Otonomi Perpustakaan (Makalah pada Rapat Kerja Pusat ke 11 dan Seminar Ilmiah Ikatan Pustakawan Indonesia, Jakarta, 5-7

November 2001)

Tjiptono,Fandy. 2004. Manajemen Jasa. Yogyakarta: Penerbit Andi 